Open Access

\title{
Comparing mission statements of social enterprises and corporate enterprises in the new and renewable energy sector of India: a computer aided content analysis study
}

\author{
Subhanjan Sengupta ${ }^{*}$ and Arunaditya Sahay
}

* Correspondence:

subhanjan.sengupta@gmail.com Birla Institute of Management Technology, Plot Number 5, Knowledge Park 2, NCR, Greater Noida, Uttar Pradesh 201306, India

\begin{abstract}
This paper aims to explore how differently corporate enterprises and social enterprises strategically position themselves through their mission statements. The most notable distinctions between the mission statements of both groups exist in the degree of action orientation, endorsements of people/groups, and the highlights of positive entailment. The new and renewable energy sector is playing a key role in the emergence of India as an environmentally conscious emerging economy. The enterprises instrumental in this change are both social and corporate enterprises. While technology is important, a key factor to success is strategic approach. The vision and mission statements are strategically crafted by organizations to position themselves in the industry. This motivated the authors to carry out a comparative analysis of the mission statements of social and corporate enterprises to learn about the existing differences. Efforts were employed to quantify the narrative style and tonality of mission statements by applying DICTION software. This process generated values for the 'master variables' and 'calculated variables' in mission statements. Content analysis revealed that while a significant number of enterprises scored zero for the calculated variable 'insistence', only a few had scores within range. Most enterprises scored considerably well in the master variable 'activity'. In 'optimism' social and corporate enterprises show some noticeable differences in their purpose, which reflect how different these organizations are. This content analysis succeeds in reflecting where the social and corporate enterprises in India's renewable energy sector differ in their strategic intent. While in renewable energy social enterprises there is a domination of reference to beneficiaries/communities in their mission statements, and the positive entailments in terms of social change; renewable energy corporate enterprises seem to have a stronger intent to focus on issues related to technology, innovation, efficiency, and cost-leadership. Thus, this paper not only adds to establishing the fact that mission statements do play an important role in reflecting the strategic purpose of the organization, but adds to the arguments on the difference between social and commercial entrepreneurship.
\end{abstract}

Keywords: Enterprise, New and renewable energy, Mission statements, Content analysis 


\section{Background}

India, being the second largest emerging economy in India, has been bolstering entrepreneurship and expansion of businesses (Gubbi 2010). 'Emerging economies' can be defined as "low income, rapid growth countries using economic liberalization as their primary engine of growth" (Hoskisson et al. 2000). It is estimated that by 2020 the GDP of BRIC (Brazil, Russia, India and China) will be among the top ten economies of the world (Economy Watch 2010). It is even estimated that by 2050, their GDP would outgrow that of G7 (Little 2008). It is estimated that by 2030, the Indian and Chinese middle class would be party to 23 and $18 \%$ respectively of global consumption, with the United States taking the third position of only 7\% (Kharas 2011). These BRIC countries ranked highest in opportunity index developed by Grant Thornton in Thornton 2012. The ocean of opportunities generated by the BRIC countries harbors the proliferation of entrepreneurial pursuits in these countries. The very nature of these economies being inconsistent in policies, harboring informal decision systems, and bearing complex social and cultural factors, is catalyst to the emergence of entrepreneurship (Tonoyan et al. 2006). Some of the common traits that can be observed to be common to all emerging economies are inconsistency and lack of clarity on policies, issues related to governance, underdeveloped institutions, lack of funding options for public as well as private projects, cultural complexities, lack of a promising education system, reluctance in internationalization, and personalized networks (Manimala \& Wasdani, 2015). These shortcomings have considerable impact on entrepreneurial pursuits, thereby creating constraints in their effort for inception and subsequent scale up. Overcoming these constraints secure a relatively higher prominent position in the entrepreneurial agenda, in comparison to designing innovation and bringing disruption. Manimala and Wasdani (2015) appropriately remark that enterprises in emerging economies "tend to develop a style of muddling through toward venture creation and growth".

With the raising concerns over the need of proliferating new and renewable energy solution in emerging economies, it has been as one of the top priorities in the agenda of the government of India. In the Paris Convention, 43 countries have agreed on 100\% renewable energy production by 2050 (UN Climate Change Newsroom 2016). World Bank is set to provide \$ 1 billion support to India's solar generation plans. The Ministry of New and Renewable Energy has targeted substantial increase in renewable energy capacity. The National Solar Mission has targeted 1,00,000 MWp by 2022 for surging India towards green energy (Press Information Bureau, Government of India 2015). The large scale of such a project would have an investment of $\$ 90$ billion. The first phase would comprise capital subsidy of $\$ 2.25$ billion to promote solar capacity addition through Rooftop Solar projects in various Indian cities and towns. The projects would be developed by the Solar Energy Corporation of India (SECI) by encouraging decentralized generation through small solar projects. On 25th February, 2017, an Indian national newspaper, Mint, reported India being the biggest greenhouse gas emitter after the US and China. As on February 2017, the new and renewable energy sector in India accounted for 15\% of the total installed power capacity of 310,005 MW. Projections show electricity consumption to be quadrupling in the next two decades. Quite consequentially, this sector has seen the rise of small, medium and large enterprises catering to the demand of the sector. While large enterprises are setting large- 
scale solar grids or wind turbines, social enterprises establish micro-grids, home solutions, or bio gas plants, to cater to the power needs of the last mile consumer who has almost none or limited access to electricity.

A report by Intellecap in 2012 revealed concentration of social enterprises in the new and renewable energy sector. While multiple factors would be instrumental in the growth and governance of these enterprises, be social enterprises or corporate enterprises, one of the factors is strategic positioning and governance. Mission statements are essential narratives which publicly communicate the purpose of the organization, its positioning in the sector, and the governance of the same (Shor and Palmer 2008). Understanding the relationship between mission statements and good governance, and exploring the components constructing mission statements is currently an area of concern and enquiry globally (Gill 2005). The mission statements of organizations are strong foundations for effective governance and sustainable growth of associated stakeholders. This motivated the authors to critically study the mission statements of two different groups of organizations and explore what makes them different. They were prompted to ask:

RQ1: How do the mission statements of social and corporate enterprises in the new and renewable energy sector differ from each other in their language tonality?

$R Q 2:$ How do the differences in the language tonality of the mission statements of social and corporate enterprises in the new and renewable energy sector would be indicative of the core purpose of these enterprises?

Answering these questions would require understanding the style of narration and choice of words in the structuring of the mission statements of these two groups of enterprises, identifying the key differences, and how that is actually reflective of the core purpose of the enterprises. The content analysis of the mission statements was computer aided, using the content analysis software DICTION, which uses 31 predefined dictionaries (containing more than 10,000 search words) in order to analyze textual content.

\section{Literature review}

Mission statement

The inception point of strategic planning is the formulation of mission statements (Khalifa 2011). In Drucker 1977, Peter Drucker commented "only a clear definition of the mission and purpose of the business makes possible clear and realistic business objectives. It is the foundation for priorities, strategies, plans, and work assignments." Bart (2001) postulates a mission statement as a formal written document constructed with the intension of capturing the core reason for the existence of the organization, which is the primary purpose that it wishes to accomplish. There are instances where the mission is a part of the vision statement (Lipton 1996). The vision statement of the Ministry of New and Renewable Energy of the Government of India, which was conveyed by the Prime Minister of India, Dr. Manmohan Singh, during the launch of India's National Action Plan on Climate Change in 2008, is one such statement that is inclusive of the strategic mission of shifting from fossil-fuel driven economy to non-fossil fuel driven economy. 
The mission statement can be identified as a tool for charting company strategy, creating a leadership position of the company, and also for influencing the perception of stakeholders (Klemm et al. 1991; Campbell 1997; Sahay and Nirjar 2006; Sahay and Sharma 2008). Williams (2008) postulated that a mission statement indicates what the enterprise intends to do, what are its priorities and values, and how that differentiates it from others. It is reflective of the culture that the organization cultivates and links with its strategic thinking (Biloslavo and Lynn 2006). Organisational values are deeply embedded in the construction and use of mission statements (Selznick 1957). The dependency of the company on the stakeholders leads to the inclusion of the stakeholders in the mission statements (Nimwegen et al. 2008). In the past, researchers have expressed concern and dissatisfaction at the quality in the content of mission statements (Khalifa 2011). Concerns had been raised on the superficiality and lack of relevance of mission statements. There had been researchers in the past that had identified mission statements as publicrelation gimmicks or 'corporate window dressing' (Nash, 1998; Wright 2002). Therefore, past research has examined the contents and purposes of mission statements, and their linkage with firm performance, especially financial performance (Bart et al. 2001; Sufi and Lyons 2003). In recent years, there has been increased attention to the degree of connections between mission statements and organizational practices; on whether the organization and its members follow the values conveyed in mission statements (Balazs 2002; Cheney et al. 2004; Bartkus and Glassman 2008). The key components that bundle together to construct mission statements are the values, growth expectations, target geographical markets, brand image, customers, and competitive advantage (David and David 2003).

In any organization, the organization's motive and purpose is reflected in its mission statement. It has been observed in past research that there are common components among the mission statements of high-performing firms (Pearce and David 1987). Even financial performance has been linked to mission statements in past research, signifying the difference between mission statements of high performing enterprises and low performing enterprises (Bart and Baetz 1998; Pearce and David 1987; Williams 2008). Past studies have also found the factors on which this relationship is dependent (Bart et al. 2001; Sidhu 2003; Sufi and Lyons 2003). Gill (2005) in his study showed that the mission statement of an enterprise is established and safeguarded by the governance of the enterprise. The relationship between mission statement and performance of top 100 state-owned corporate in China revealed that corporate mission statements concerned with customers and suppliers, products and services, as well as technology and growth factors, are significantly associated with economically responsible performance (Erming and Yan-Yan 2011). On the other hand, those mission statements, which focus on issues like nation, employee, societies and environment, were not significantly associated with performance.

Past research has shown consensus among senior managers on the fact that mission statements had been consistently used as a tool by the management of an organization in the course of its evolution in its life cycle. It is surprising to note that despite the prominence that mission statements carry, considering the popular talk regarding it amongst academicians and practitioners, there is inadequate quantity and quality of research on mission statements (Bart et al. 2001). 


\section{New and renewable energy}

Energy has strong association, direct or indirect, with income generation, health-care, facilitation of education, improved living standards, poverty reduction, and many other matters pertaining to human development (Biswas et al. 2001; Sagar 2005; Sharma 2007). However, in emerging economies, the CO2 emissions have been quite high, owing to the voluminous energy consumption as a consequence of rapid economic growth (Piñeiro Chousa et al. 2008).

Energy consumption and the impact of the same on the environment have been under the surveillance of developed countries for quite some time. Considering it as an ethical responsibility onto themselves, these countries have been promoting energy conservation programs for higher efficiency in energy usage (Dernbach and Brown 2009). By 2020, Europe aims at reducing greenhouse gas emission by $20 \%$, and increase renewable energy sources by $20 \%$ (Abrell and Weigt 2005). It is a humongous task to cultivate consciousness of environmental degradation in conjunction with arranging access to electricity for the vast off-grid geographical spread of an emerging economy like India. That is where renewable energy technologies offer solutions affordable and feasible for the last-mile consumers, while avoiding the detrimental impact of fossil fuel consumption (Kolk and Buuse 2012). In the vision statement of the Ministry of New and Renewable Energy of the Government of India as formulated by the Prime Minister of India, Dr. Manmohan Singh, in 2008, the potential of significant change in the economy due to the development of new and renewable energy appears distinct and focused:

In this strategy, the sun occupies center-stage, as it should, being literally the original source of all energy. We will pool our scientific, technical and managerial talents, with sufficient financial resources, to develop solar energy as a source of abundant energy to power our economy and to transform the lives of our people. Our success in this endeavor will change the face of India. It would also enable India to help change the destinies of people around the world.

However, it is easier said than done. The challenges are as enormous as much as the opportunities. The establishment and sustenance of enterprises for achieving the renewable energy mission demands financial support and a favorable policy driven environment. The earlier, as well as the present government, has been working extensively on it. The raising importance associated by the government of India with new and renewable energy triggered a policy driven environment for enabling large and small, social and corporate enterprises, enter this sector with different kinds of partnerships and capital capacities (Kolk and Buuse 2012). Enterprises have been trying to design viable business models that can generate power for different consumer segments using new and renewable energy sources. While for-profit corporate enterprises would cater to only those markets where there is potential of profit-generation, social enterprise play a significant role in rural electrification with off-grid energy solutions.

\section{Social and corporate enterprises}

Efforts to define social enterprises abound with lack of agreement among the fraternity of researchers on a single definition, thereby leading to definitional confusions (Mair and Marti 2006; Short et al. 2009; Doherty et al. 2014; Sengupta and Sahay 2017). Years 
of research and debate has led the contested concept of social entrepreneurship evolve into a cluster concept which is inclusive of four constructs that come together to create social value: social innovation, market orientation, social entrepreneur and the social enterprise organization (Choi and Majumdar 2014). The review of literature conducted by Sengupta and Sahay (2017) reveals that a common consensus among past researchers reveal that social enterprises are "hybrid enterprises with dual purposes of social value creation and market orientation, at varying degrees, to achieve a double bottom line of economic and social wealth". These enterprises pursue public purposes by employing private means, and solve social issues outside state or market imposed limitations (Halpern 1997). They can be defined as "high-impact ventures that address long-standing socio-environmental problems, focus on long-term collaborative community capacity building, rely on collective wisdom and experience, foster the creation of knowledge and networks and facilitate sustained positive social change" (Trivedi and Stokols 2011). Though researchers have been trying to conceptually define social enterprises, the legal system and structure of India has not been able to legally define social enterprises, which made this particular research difficult in terms of identifying sample enterprises for the study.

Contrary to social enterprises, corporate enterprises are those with strong commercial objective of economic value creation through wealth maximization of shareholders. They grow around the objective of meeting market demand profitably; where as a social enterprise is focused on addressing market failures (Suarez-Villa 2009; Trivedi and Stokols 2011). Due to higher financial support from venture capitalists, banks, and other financial institutions, corporate entrepreneurs are relatively less bound by constraint of resources. They are comparatively at a more advantageous position to accumulate the best of resources due to the strong market oriented approach. Business planning, in the form of market research, business analytics, financial planning, strategic planning, are also of higher importance in corporate enterprises in order to achieve financial sustainability (Zietlow 2001; Rouson 2005). Relative to social enterprises, corporate enterprises are more concerned with the macro-economic environment, such as socio-political incidents, tax and regulations, technological disruptions and advancements, because the pace and aggressiveness for scale-up is comparatively higher (Peredo and Chrisman 2006). The key point of difference is whether social value creation is a primary objective, or a secondary one; for social enterprises it is primary, whereas for corporate enterprises it is not a primary motive (Trivedi and Stokols 2011). For a corporate enterprise, the purpose is the earning of profit by offering a product or service so as to maximize wealth for shareholders (Friedman 2007). Social enterprises combine elements of business sector and social sector with the sole purpose of addressing social problems; which is quite contrary to the prominence given to the generation of market value over social value (Giddens 1998; Suarez-Villa 2009).

\section{Research gap}

A search for peer-reviewed scholarly literature combining the keywords 'mission statement' and 'social enterprise' led to only one peer reviewed full-text paper. The paper was not a study of mission statements of social enterprises vis-à-vis that of corporate enterprises; but on the legitimacy of the institution under study, in conformance to its mission statement. A similar search combining the keywords 'mission statement' and 'corporate enterprise' or 'business' led to some peer-reviewed journal articles which 
ranged on a variety of issues related to mission statements, but none studying how the mission statements reflect how different social and corporate enterprises are from each other in their strategic intent.

This made the authors feel the need of doing a comparative study between mission statements of social enterprises and corporate enterprises, as that would be a good starting point to understand what differentiates these two types of enterprises.

\section{Methods}

This research analyzes the mission statements of NRE-SEs (new and renewable energy social enterprises) and NRE-CEs (new and renewable energy corporate enterprises). No consolidated list of social enterprises exists on government records; which is understandable in an emerging economy like India which has not legally defined 'social enterprises'. Therefore, NRE-SEs were identified from the list of social enterprises enlisted with the Ashoka Fellowship, Action for India, Sankalp Forum, Pravah Changelooms, and School for Social Entrepreneurs India. The total number of NRE-SEs whose mission statements were available for this study was ten. The reason for this were that, (a) not many renewable energy social enterprises are listed on the portals stated above, (b) many renewable energy social enterprises are still start-ups and some do not even have websites, and (c) some of those renewable energy social enterprises which have websites, they do not have Vision and Mission statements clearly mentioned. To compare the mission statement content of these ten NRE-SEs with mission statements of NRECEs, ten corporate enterprises in NRE sector were selected whose mission statements were available. The limitation that the authors had in choosing of enterprises for study was that they were not able to segregate the lists of empanelled agencies with the Ministry of New and Renewable Energy; primarily due to the lack of classification between social enterprises and corporate enterprises in the list of empanelment, and absence of some social enterprises in those very lists. This calls for some efforts on the side of the government to come up with a legal identity of social enterprises and incorporate that in its listing of companies. Due to this limitation, this study was not able to benefit from exhaustive list of companies that the government has on its websites. The names of the NRE-SEs and NRE-CEs have not been disclosed as this research does not in any way intend to criticize any company/brand. Since the objective is only to learn and share findings related to how differently corporate enterprises and social enterprises strategically position themselves in the sector through their mission statements, there is no intension to - appreciate or criticize specific enterprises.

The qualitative approach of this research methodology applies content analysis, using a set of procedures, to identify differences among the tonality of the mission statements (Weber 1990). This enables the researchers to observe the difference in the intensity of beliefs and values that the two different groups of institutions hold. The mission statements studied in this research were analyzed using DICTION 5.0 software package. In order to execute content analysis, DICTION software was used. It is a widely acknowledged tool for generating results which are very reliable, and significantly reduces speed and cost that would have been incurred if coding was done by humans (Rosenberg et al. 1990). DICTION is used in strategic management research for analyzing textual content like mission statements, CEO interviews, annual reports, leadership speeches, 
and any other textual/narrative data that are important indicators of the strategic intent of organizations/enterprises/bodies (Shor and Palmer 2008). The software had undergone rich development process, based on linguistic theory, and the variables which demonstrate language tonalities are designed considering all words and expressions present in the English language. The DICTION based content analysis procedure quantifies language tonalities and represents that in the form of Master Variables and Calculated Variables. DICTION searches the text for 5 Master Variables (MV). The results of these variables are generated by DICTION on the basis of word-lists from 31 dictionaries. DICTION also generates results for 4 Calculated Variables (CV) based on calculations of word ratios, rather than matches from dictionaries. While the MVs capture tonal features of the text, the CVs indicate frequency of expressions containing those variables. The meaning of these MVs and CVs are explained in Table 1. The values of these variables have their own defined range; scores above and below the range show lack of the respective quality. These are the only two categories of variables that are pre-defined by DICTION and consider the total diversity of the English language.

\section{Results and discussions}

The DICTION results of NRE-SEs' and NRE-CEs' master and calculated variables are displayed in Table 2. The identity of the NRE-SEs and NRE-CEs are not revealed in the course of this discussion as the objective of this research is not to give opinion on an enterprise by its name, but to look at existing differences or commonalities in the mission statements of NRE-SEs and NRE-CEs; results that give insights into the philosophies and strategies that drive the enterprises/businesses (Leuthesser \& Kohli, 1997).

Table 1 Definition of Master Variables and Calculated Variables as followed by DICTION*

\begin{tabular}{|c|c|}
\hline & Assumptions \\
\hline \multicolumn{2}{|l|}{ Calculated Variables } \\
\hline 1) Insistence & $\begin{array}{l}\text { Repetition of key terms indicates a preference for a limited, } \\
\text { ordered world. }\end{array}$ \\
\hline 2) Embellishment & $\begin{array}{l}\text { Heavy modification slows down a verbal passage by } \\
\text { de-emphasizing human and material action. }\end{array}$ \\
\hline 3) Variety & $\begin{array}{l}\text { A high score indicates a speaker's avoidance of overstatement } \\
\text { and a preference for precise, } \\
\text { molecular statements. }\end{array}$ \\
\hline 4) Complexity & $\begin{array}{l}\text { Convoluted phrasings make a text's ideas abstract and its } \\
\text { implications unclear. }\end{array}$ \\
\hline \multicolumn{2}{|l|}{ Master Variables } \\
\hline 1) Activity & $\begin{array}{l}\text { Language featuring movement, change, the implementation } \\
\text { of ideas and the avoidance of inertia. }\end{array}$ \\
\hline 2) Optimism & $\begin{array}{l}\text { Language endorsing some person, group, concept or event } \\
\text { or highlighting their positive entailments. }\end{array}$ \\
\hline 3) Certainty & $\begin{array}{l}\text { Language indicating resoluteness, inflexibility, and } \\
\text { completeness and a tendency to speak ex cathedra }\end{array}$ \\
\hline 4) Realism & $\begin{array}{l}\text { Language describing tangible, immediate, recognizable } \\
\text { matters that affect people's everyday lives. }\end{array}$ \\
\hline 5) Commonality & $\begin{array}{l}\text { Language highlighting the agreed -upon values of a } \\
\text { group and rejecting idiosyncratic modes of engagement. }\end{array}$ \\
\hline
\end{tabular}

*Source: Help Manual, Digitext, Inc. 2/26/2014 (http://www.dictionsoftware.com/download.php?file=wp-content/uploads/2014/ 02/DICTION-7-Manual-2-26-14.pdf.), Accessed on 27/07/2017 
Table 2 DICTION Master Variables (MV) and Calculated Variables (CV) of NRE-SEs and NRE-CES

\begin{tabular}{|c|c|c|c|c|c|c|c|c|c|c|c|c|}
\hline \multicolumn{13}{|l|}{ NRE-SES } \\
\hline & \multicolumn{12}{|c|}{ Range } \\
\hline & Low & High & SE1 & SE2 & SE3 & SE4 & SE5 & SE6 & SE7 & SE8 & SE9 & SE10 \\
\hline \multicolumn{13}{|l|}{ CV } \\
\hline Insistence & 9.15 & 111.15 & $0^{*}$ & $4.17^{*}$ & $0^{*}$ & $0^{*}$ & $4.17^{*}$ & 84.48 & $0^{*}$ & 12.95 & $3.7^{*}$ & $3.33^{*}$ \\
\hline Embellishment & 0.16 & 1.14 & $26^{*}$ & $0.05^{*}$ & 1 & $0.07^{*}$ & $0.05^{*}$ & 0.77 & $0.08^{*}$ & 0.56 & 1 & $0.03^{*}$ \\
\hline Variety & 0.45 & 0.53 & $1^{*}$ & $0.83^{*}$ & $1^{*}$ & $0.85^{*}$ & $0.92^{*}$ & $0.76^{*}$ & $0.78^{*}$ & $0.7^{*}$ & $0.89^{*}$ & $0.83^{*}$ \\
\hline Complexity & 4.31 & 4.91 & $5.65^{*}$ & $5.38^{*}$ & $5.89^{*}$ & $6^{*}$ & $6.75^{*}$ & $5.22^{*}$ & $5.91^{*}$ & $5.57^{*}$ & $5.7^{*}$ & $5.1^{*}$ \\
\hline \multicolumn{13}{|l|}{ MV } \\
\hline Activity & 46.74 & 55.48 & $2.29^{*}$ & 47.5 & 47.57 & $40.41^{*}$ & 53.95 & 51.28 & 50.7 & 51.93 & 49.54 & 53.1 \\
\hline Optimism & 46.37 & 52.25 & $40.94^{*}$ & $54.02^{*}$ & 49.66 & $56.9^{*}$ & 49.66 & 46.3 & 49.57 & $46.17^{*}$ & 50.33 & 49.66 \\
\hline Certainty & 46.90 & 51.96 & $31.37^{*}$ & $44.24^{*}$ & $46.43^{*}$ & $39.94^{*}$ & $39.63^{*}$ & $41.12^{*}$ & $43.01^{*}$ & $43.84^{*}$ & $32.16^{*}$ & $39.51^{*}$ \\
\hline Realism & 46.10 & 52.62 & $41.45^{*}$ & $39.03^{*}$ & $31.1^{*}$ & $41.02^{*}$ & $41.79^{*}$ & $60.8^{*}$ & $46.08^{*}$ & 48.5 & 49.87 & $58.03^{*}$ \\
\hline Commonality & 46.86 & 52.28 & 49.17 & 49.17 & 49.17 & $55.67^{*}$ & $54.32^{*}$ & $56.15^{*}$ & $41.04^{*}$ & $54.68^{*}$ & $54.99^{*}$ & $63.78^{*}$ \\
\hline \multicolumn{13}{|l|}{ * out of range } \\
\hline \multicolumn{13}{|l|}{ NRE-CES } \\
\hline & \multicolumn{12}{|c|}{ Range } \\
\hline & Low & High & CE1 & CE2 & CE3 & CE4 & CE5 & CE6 & CE7 & CE8 & CE9 & CE10 \\
\hline \multicolumn{13}{|l|}{$C V$} \\
\hline Insistence & 9.15 & 111.15 & 27.27 & $0^{*}$ & $0^{*}$ & $0^{*}$ & $0^{*}$ & 12.16 & 40.43 & $0^{*}$ & $0^{*}$ & $0^{*}$ \\
\hline Embellishment & 0.16 & 1.14 & 1 & 1 & 1 & $0.02^{*}$ & 1 & $0.13^{*}$ & 0.89 & 1 & $0.04^{*}$ & $0.06^{*}$ \\
\hline Variety & 0.45 & 0.53 & $0.59^{*}$ & $0.86^{*}$ & $0.85^{*}$ & $0.87^{*}$ & $0.89^{*}$ & $0.78^{*}$ & $0.6^{*}$ & $0.86^{*}$ & $0.9^{*}$ & $0.85^{*}$ \\
\hline Complexity & 4.31 & 4.91 & 4.75 & $6.21^{*}$ & $5.38^{*}$ & $5.47^{*}$ & $6.17^{*}$ & $5.1^{*}$ & $4.97^{*}$ & $6.21^{*}$ & $5.9^{*}$ & $6.19^{*}$ \\
\hline \multicolumn{13}{|l|}{ MV } \\
\hline Activity & 46.74 & 55.48 & 47.68 & 55.16 & 50.7 & $68.46^{*}$ & 55.19 & 52.41 & 48.16 & 55.16 & $38.29^{*}$ & 47.45 \\
\hline Optimism & 46.37 & 52.25 & $52.99^{*}$ & 49.66 & $52.73^{*}$ & $54.22^{*}$ & $59.54^{*}$ & $52.48^{*}$ & $57.84^{*}$ & 49.66 & $54.89^{*}$ & 51.73 \\
\hline Certainty & 46.90 & 51.96 & 49.81 & $35.65^{*}$ & $41.52^{*}$ & $40.72^{*}$ & $42.03^{*}$ & $45.8^{*}$ & $56.37^{*}$ & $35.65^{*}$ & 49.1 & $41.82^{*}$ \\
\hline Realism & 46.10 & 52.62 & $57.03^{*}$ & $35.97^{*}$ & $42.76^{*}$ & 50.95 & $39.52^{*}$ & 46.64 & 47.56 & $35.97^{*}$ & $43.15^{*}$ & $39.4^{*}$ \\
\hline Commonality & 46.86 & 52.28 & $39.54^{*}$ & $80.47^{*}$ & 49.17 & $40.03^{*}$ & $56.97^{*}$ & $48.9^{*}$ & $57.56^{*}$ & $80.47^{*}$ & $57.03^{*}$ & 50.57 \\
\hline * out of range & & & & & & & & & & & & \\
\hline
\end{tabular}

The DICTION scores (Table 2) reveal a very interesting fact that four out of ten SEs, and seven out of ten CEs, score nothing in terms of the calculated variable 'Insistence'. This means that these enterprises show very limited signs in their mission statements of any specific preference for an ordered world. For instance, one of the NRE-CE mentions in its mission statement that it wants to "make a significant and lasting contribution to the environment and to achieve sustainable development". This is a very general statement showing lack of 'insistence' on a world order that a social enterprise would specifically have to address. The NRE-SE (SE6) which had the highest score for 'insistence' refers to Indian poor more than once in their mission statement and highlights the social and infrastructural change needed in access to electricity, which it intends to bridge. In their mission statement they mention: 
Improve the lives of India's urban poor by giving them access to sustainable products that make their lives better, and empower local Indian entrepreneurs to be a positive force for change in India's urban poor communities.

Another NRE-SE mentions in its mission statement that it wants to:

Eradicate deadly killers like kerosene and ensure a more energy-equitable future for millions of BOP households.

Low 'Insistence' also signifies being non-repetitive of what is crucial to the enterprise. The NRE-CE (CE7) with highest score for 'insistence' refers to its USP more than once in its mission statement, which is low-cost power production, and stresses on the lack of the same in India. Its mission statement says:

Our mission is to be the lowest-cost power producer in the world. We sell solar power in India on long-term fixed price contracts to our customers, at prices which in many cases are at or below prevailing alternatives for these customers.

These statements indicate an underlying worldview on the need of a specific social issue which they plan to address.

Enterprises with no score in 'insistence' do not talk of a world order they want to see. For example, NRE-SE1 talks about replacing kerosene as a fuel, or NRE-CE 5 talks mostly about satisfying shareholders. But there are more social enterprises than corporate enterprises showing concern and preference for a world order.

The DICTION scores reveal another interesting fact that two out of ten NRE-SEs, and two out of ten NRE-CEs, score outside the range in the master variable 'Activity'; both NRE-SEs and one NRE-CE scoring low, and the other NRE-CE scoring high. The rest NRESEs and NRE-CEs seem to be implying dynamic approach and action in terms of implementing change. For instance, one of the NRE-CEs mentions in its mission statement:

We bring conviction and commitment to in all aspects of our work which helps us work better as a team; collaborating in arriving at solutions for every problem and challenge, making us responsible not only to our clients, but also to every team member in our organization.

The NRE-CE scoring very high, beyond the range, talks about building network, cost leadership strategy, with focus on moving "up the value chain through rapid development of technology, products and services". The NRE-CE with low scores in 'activity', states more of how it wants itself to be perceived by the market, but does not talk of an action-oriented mission. It says that its mission is to be the "lowest cost power producer of the world". One of the NRE-SEs which scored well in 'activity', indicates action oriented approach by mentioning that its mission is to 'empower' its customers with a complete solution in terms of product and service. It says that its mission is:

To empower its customer by providing a complete package of product, service and consumer financing through grameen banks, cooperative societies, commercial banks and micro-finance institutions. 
Similarly, another NRE-SE gives quite an action oriented mission statement. It mentions that it is focused on:

Enabling individuals, households, institutions, and small businesses to embrace sustainability in their daily activities.

Another NRE-SE mentions that its mission is:

To provide clean energy access to the 450 million people without access to reliable electricity in rural India.

Here it is talking of a specific action that it wants to attain for achieving a specific objective. What is interesting to note in the case of both NRE-CEs and NRE-SEs, is that both perform more or less at par in terms of 'activity', but with very different objectives: NRE-CEs with focus on technology, business and innovation, and NRE-SEs with focus on renewable energy as a tool for social change. For instance NRE-CE 2 mentions in its mission statement:

Since inception, we have achieved a substantial reduction in total solar project cost, which includes a significant decrease in balance of systems costs due in part to our value engineering, design and procurement efforts.

The mission statement of NRE-CE 5 talks about providing state-of-the art technology and smart strategic solutions. The say that their mission is:

To achieve, sustain and maintain total satisfaction of all stakeholders by providing state of the art technology and sound business strategies.

The mission statements of NRE-SEs and NRE-CEs show differences for the master variable 'optimism'. This means that the mission statements of both groups differ in endorsements of people or concepts, or in highlighting positive entailments.

It was observed in this sample that the language of NRE-SEs were quite prone towards "endorsing some person, group, concept or event or highlighting their positive entailments", as the definition of 'optimism' goes in the DICTION software. One of the NRE-SEs makes references to its engagement with community through the nurturing of imagination and inception of innovation at community level so as to bolster confidence in the community in accepting new and renewable energy. That is reflected in the kind of business that the company is in; which is, training of rural youth in becoming micro-entrepreneurs who can build small solar power appliances by themselves. It says in its mission statement:

Our Mission is to nurture imagination, instill curiosity, incept innovation, and bolster confidence in youth \& community by bringing DIY hands on green energy workshops, curriculum, and advocacy for peer to peer learning, awareness \& entrepreneurship development across India.

One of the NRE-SEs refers to multiple stakeholders in its mission statement, talks about the positive entailments that they offer in terms of bringing the last mile citizens 
of the human civilization from the least of priorities to topmost priority. They state that their mission is to:

Channelize the largely dissociated efforts of various stakeholders - communities, investors, entrepreneurs, businesses, government and the society at large - to bring the worldwide impoverished and under-served rural population from the bottom to the top of the list of priorities.

NRE-CEs also exude positive entailments, but more in terms of technological development enabling them to grow and scale up. For example, one of the NRE-CEs say that they aim at technological development so as to move up the value chain, leverage cost-leadership, and emerge as a global leader. They mention that their mission statement:

We will move up the value chain through rapid development of technology, products and services. We will leverage our relationships, distribution, cost leadership and "can do" attitude to become a global market leader in every business.

It is not a surprise for such perspective to come from this NRE-CE as the renewable energy wing is just another business of the mother company which is one of the technology leaders in India. Quite similarly, another NRE-CE talks about its mission being one of the lowest-cost power producers of the world, and makes references to customer groups in its mission statement; stressing that their customers find their products and services at more attractive prices in comparison to available alternatives. They actually sound quite 'optimistic' about themselves. Their mission statement is:

Our mission is to be the lowest-cost power producer in the world. We sell solar power in India on long-term fixed price contracts to our customers, at prices which in many cases are at or below prevailing alternatives for these customers. Since inception, we have achieved a substantial reduction in total solar project cost, which includes a significant decrease in balance of systems costs due in part to our value engineering, design and procurement efforts.

Another NRE-CE makes repeated reference to its clients and highlights their positive entailments, like conviction, commitment, collaboration, continuous innovation, quality and efficiency standards, honest and transparent dealings, which are the key things keeping their clients happy. They say in their mission statement:

We believe in dealing honestly and transparently, to build trust in our relationships. Each and every member, client and associate is important to us to learn from and share.

What is observed therefore in NRE-SEs is that there is a domination of reference to beneficiaries/communities in their mission statements, and the positive entailments in terms of social change; whereas NRE-CEs seems to have a stronger intent to focus on issues related to technology, innovation, efficiency, cost-leadership, and sustainability. One of the NRE-CEs mentions that their mission is to: 
Generate Green Power through Renewable Energy sources viz. Biomass, Small Hydro, Solar and Wind, delivered at competitive price while achieving the satisfaction of all stakeholders with the committed participation of all employees and meeting environmental norms.

This mission statement has a strong score of 57.84 (higher than top limit of range) in 'optimism'.

The differences in the mission statements of the two groups is reflective of the conceptual development of the phenomenon among the community of researchers, in terms of the degree of association that social and corporate enterprises have with the social change needed at community level, vis-à-vis the importance given to technological advancement and business leadership prioritized by corporate enterprises. The content analysis conducted in this research indicates academic research being on the same thought trajectories as in practice.

\section{Implications of the study}

What an organization intends to do and wants to be seen as in the long run is integral to organizational culture and climate. It conveys this through oral as well as symbolic communication (Gordon 2017). Vision and mission statements are the highest level of communication that an organization has, and its performance is often evaluated or audited in terms of the fitment with the vision and mission statements; these statements being formal communication of an organization regarding its purpose and future position. These statements are no longer considered as 'decorative devices', but as instruments mobilizing employees and stakeholders towards specific objectives (Verma 2010).

This study took cognizance of this fact and addressed the often discussed difference between social and corporate entrepreneurship with a computer-aided content analysis of one of the most fundamental strategic tools - Mission Statements. This study has relevance to researchers and practitioners because of its novelty, which lies in the fact that this approach has not been used before to address the debate between social and commercial entrepreneurship. The use of DICTION was helpful in identifying the unobservable patterns in the mission statements of NRE-SEs and NRE-CEs. The use of artificial intelligence like DICTION, which is computer-aided content analysis, has facilitated in quantifying the nature of language usage in these mission statements. Such methodology is a reliable tool in strategic management research (Ober et al. 1999; Hunter 2003). We can relate the findings to the fact that social enterprises are different from corporate enterprises in terms of the emphasis that they place on serving the communities, rather than giving more value to being strategic in business or becoming global leaders in innovation and technology. The unraveling of the differences in the tonalities of the mission statements reflects differences in the way the enterprises have positioned themselves in the NRE sector. That implies the fundamental purpose of these organizations, which the shareholders as well as stakeholders consider in their evaluation of why the enterprise exists and what prospects it may possibly hold in the times to come. 


\title{
Conclusion
}

This study had looked into the narrative pattern and choice of words in mission statements. But there is a need to empirically study the structural, institutional and contextual factors that go into formulating vision and mission statements of these enterprises. There is also a need to study how both social and corporate enterprises are contributing to the growth of the NRE sector in an emerging economy like India, and what common or different connections, institutions, and network they access while working in the sector. Another study possibility is computer-aided content analysis of NRE social and corporate enterprises across all the leading emerging economies - BRICS (Brazil, Russia, India, and China). Apart from this, another significant study would be a comparative study between the strategic decisions in NRE social and corporate enterprises in the context of emerging economies to understand how different these enterprises operate and create impact. Considering the fact that mission statements are an elementary strategic tool, this study can be a good starting point for all these necessary studies.

\begin{abstract}
Acknowledgements
The authors wish to acknowledge the critical feedback and support received from the Centre of Research, Birla Institute of Management Technology, Greater Noida. They also wish to acknowledge the mentorship on methodology, received from Dr. Srinath Jagannathan of Indian Institute of Management, Indore. They also wish to acknowledge the support of Dr. Pooja Ghosh of IIT, Delhi, for technical assistance.

Funding

None.

Author details

Subhanjan Sengupta is pursuing his doctoral program at Birla Institute of Management Technology (BIMTECH), Greater Noida, where the PhD program is affiliated to Mohanlal Sukhadia University, Udaipur. He has teaching experience in marketing management, strategy, social entrepreneurship, and development of life skills. His research interests are strategic management, sustainable development, social entrepreneurship, and qualitative research methodologies. He is also a pro-active case writer. He is the corresponding author and can be contacted at: subhanjan.sengupta@gmail.com Arunaditya Sahay is a Professor of Strategic Management and a Dean of Research at Birla Institute of Management Technology, Greater Noida. His teaching and research interests include innovation, entrepreneurship, sustainability and CSR. He has been a turnaround manager, corporate entrepreneur, researcher, educator and an institution builder. He has advised leading companies in the area of "Corporate Strategy". He was the lead consultant in many projects sponsored by European Union, Govt. of India and corporates. He can be reached at arun.sahay@bimtech.ac.in.
\end{abstract}

\section{Authors' contributions}

SS carried out literature review, data collection, data analysis, and drafting of the paper. AS participated actively in setting the epistemological orientation of the research, planning of the research methodology, conducting data analysis, and the drafting of the paper. Both authors read and approved the final manuscript.

Competing interests

The authors declare that they have no competing interests.

\section{Publisher's Note}

Springer Nature remains neutral with regard to jurisdictional claims in published maps and institutional affiliations.

Received: 29 June 2017 Accepted: 13 September 2017

Published online: 18 September 2017

References

Abrell, J., \& Weigt, H. (2005). "The interaction of emissions trading and renewable energy promotion", working paper no. In WP-EGW-05. Dresden: Dresden University of Technology https://papers.ssrn.com/sol3/papers2.cfm?abstract_ $i d=1317310$. (Accessed Feb 2017.

Balazs, K. (2002). Take one entrepreneur: The recipe for success of France's great chefs. European Management Review, 20, 247-259.

Bart, C. K. (2001). Exploring the application of mission statements on the world wide web. Internet Research: Electronic Networking Applications and Policy, 11, 360-368.

Bart, C. K., \& Baetz, M. C. (1998). The relationship between mission statements and firm performance: An exploratory study. The Journal of Management Studies, 36, 823-853. 
Bart, C. K., Bontis, N., \& Taggar, S. (2001). A model of the impact of mission statements on firm performance. Management Decision, 39, 9-30.

Bartkus, B., \& Glassman, M. (2008). Do firms practice what they preach? The relationship between mission statements and stakeholder management. Journal of Business Ethics, 83, 207-216.

Biloslavo, R., \& Lynn, M. (2006). Mission statements in Slovene enterprises. Management Decision, 45(4), 773-788.

Biswas, W., Bryce, P., \& Diesendorf, M. (2001). Photovoltaic technologies for poverty alleviation in rural Bangladesh. Environmental Science and Policy, 4, 333-344.

Campbell, A. (1997). Mission statements. Long Range Planning, 30(6), 931-932.

Cheney, G., Christensen, L. T., Conrad, C., \& Lair, D. J. (2004). Corporate rhetoric as organizational discourse. The Sage handbook of organizational discourse, pp., 79-103.

Choi, N., \& Majumdar, S. (2014). Social entrepreneurship as an essentially contested concept: Opening a new avenue for systematic future research. Journal of Business Venturing, 29(3), 363-376.

David, F. R., \& David, F. R. (2003). It's time to redraft your mission statement. Journal of Business Strategy, 24(1), 11-14.

Dernbach, J. C., \& Brown, D. A. (2009). The ethical responsibility to reduce energy consumption. Hofstra Law Review, 37, $985-1005$.

Doherty, B., Haugh, H., \& Lyon, F. (2014). Social enterprises as hybrid organizations: A review and research agenda. International Journal of Management Reviews, 16(4), 417-436.

Drucker, P. F. (1977). An introductory view of management. NewYork, NY: Harper's College Press.

Er-ming, X., \& Yan-Yan, X. (2011). "The relationship between mission statements and corporate social performance", paper presented at 18th international conference on management sciences \& engineering. Rome, Italy, September, 13-15, 2011 http://ieeexplore.ieee.org/abstract/document/6069977/?reload=true. (Accessed 24 Feb 2017.

Friedman, J. P. (Ed.). (2007). Dictionary of business terms (4th ed.). Portland, OR: Barron's Educational Series.

Giddens, A. (1998). The third way: The renewal of social democracy. Cambridge: Polity Press.

Gill, M. (2005). Governing for results: A director's guide to good governance. Trafford Publishing.

Gordon, G. (2017). Leadership through trust. USA: Palgrave Macmillan.

Gubbi, R. S. (2010). Do international acquisitions by emerging-economy firms create shareholder value? The case of Indian firms. Journal of International Business Studies, 41, 397-418.

Halpern, C. (1997). Preface. In L. M. Salamon (Ed.), Holding the center: America's nonprofit sector at a crossroads. New York: The Nathan Cummings Foundation.

Hoskisson, R.E, Eden, L., Lau, C.M. and Wright, M. (2000), "Strategy in emerging economies", Acad Manag J, Vol. 43 or no. 3, pp. 249-267.

Hunter, S. D. (2003). Information technology, organizational learning, and the market value of the firm. Journal of Information Technology Theory and Application, 5, 1-28

Intellecap (2012). On the path to sustainability and scale. A study of India's social enterprise landscape. Available at: http://intellecap.com/publications/path-sustainability-and-scale-study-indias-social-enterprise-landscape. (Accessed on Feb 2017).

Khalifa, A. S. (2011). Three F's for the mission statement: what's next? Journal of Strategy and Management, 4(1), 25-43.

Kharas, H. (2011). "The emerging middle class in developing countries", working paper. No., 285 http://unpan1.un.org/ intradoc/groups/public/documents/un-dpadm/unpan044413.pdf. (Aaccessed on Feb 2017.

Klemm, M., Sanderson, S., \& Luffman, G. (1991). Mission statements: Selling corporate values to employees. Long Range Planning, 24(3), 73-78.

Kolk, A., \& Buuse, D. (2012). In search of viable business models for development: Sustainable energy in developing countries. Corporate Governance: The international journal of business in society, 12(4), 551-567.

Leuthesser, L., \& Kohli, C. (1997). Corporate identity: The role of mission statements. Business Horizons, 40(3), 59-66.

Lipton, M. (1996). Demystifying the development of an organizational vision. Sloan Management Review, 37(4), 83-92.

Little, A. D. (2008). The BRIC battle: winning the global race for the emerging middle segment http://www.adlittle.com/ downloads/tx_adlreports/ADL_BRIC.pdf. (accessed 24 Feb 2017.

Mair, J., \& Marti, I. (2006). Social entrepreneurship research: A source of explanation, prediction, and delight. Journal of World Business, 41(1), 36-44.

Manimala, M. J. \& Wasdani, K. (2015). Entrepreneurial Ecosystem. Springer, India.Nimwegen, G. V., Bollen, L., Hassink, H., \& Thijssens, T. (2008). A stakeholder perspective on mission statements: An international empirical study. International Journal of Organizational Analysis, 16(1), 61-82.

Ober, S., Zhao, J. J., Davis, R., \& Alexander, M. W. (1999). Telling it like it is: The use of certainty in public business discourse. Journal of Business Communication, 36, 280-300.

Pearce, J. A., \& David, F. (1987). Corporate mission statements: The bottom line. Academy of Management Executive, 1, 109-115.

Peredo, A. M., \& Chrisman, J. J. (2006). Toward a theory of community based enterprise. Academy of Management Review, 31(2), 309-328.

Piñeiro Chousa, J., Tamazian, A. and Chaitanya, V.K. (2008), "Rapid economic growth at the cost of environment degradation? - Panel data evidence from BRIC economies", working paper No. 908, William Davidson Institute, Available at: https://papers.ssrn.com/sol3/papers2.cfm?abstract_id=1143537. (Accessed Feb 2017).

Press Information Bureau, Government of India, Cabinet June 2015, Available at: http://pib.nic.in/newsite/PrintRelease. aspx?relid=122566. (Accessed Feb 2017).

Rosenberg, S. D., Schnurr, P. P., \& Oxman, T. E. (1990). Content analysis: A comparison of manual and computerized systems. Journal of Personality Assessment, 54, 298-310.

Rouson, B. (2005). Business planning for nonprofits: Why, when-And how it compares to strategic planning. Enhance, 2(1), 1-12.

Sagar, A. (2005). Alleviating energy poverty for the world's poor. Energy Policy, 33, 1367-1372.

Sahay, A., \& Nirjar, A. (2006). Entrepreneurship: Education. Research and Practice: Excel Books, New Delhi.

Sahay, A., \& Sharma, V. (2008). Entrepreneurship and new venture creation. New Delhi: Excel Books.

Selznick, P. (1957). Leadership in administration: A sociological interpretation. Berkeley: California.

Sengupta, S., \& Sahay, A. (2017). Social entrepreneurship research in Asia-Pacific: Perspectives and opportunities. Social Enterprise Journal, 53(1), 17-37. 
Sharma, D. (2007). Transforming rural lives through decentralized green power. Futures, 39, 583-596.

Shor, J. C., \& Palmer, T. B. (2008). The application of DICTION to content analysis research in strategic management. Organisational Research Methods., 11(4), 727-752.

Short, J. C., Moss, T. W., \& Lumpkin, G. T. (2009). Research in social entrepreneurship: Past contributions and future opportunities. Strategic Entrepreneurship Journal, 3(2), 161-194.

Sidhu, J. (2003). Mission statements: Is it time to shelve them? European Management Journal, 21, 439-446.

Suarez-Villa, L. (2009). Creativity as a commodity. In L. Suarez-Villa (Ed.), Technocapitalism: A critical perspective on technological innovation and corporation. Philadelphia: Temple University Press.

Sufi, T., \& Lyons, H. (2003). Mission statements exposed. International Contemporany Hospitality Management, 15, 255-262.

Thornton, G. (2012). Emerging markets opportunity index: High growth economies. International Business Report: Emerging Markets, 2012 http://www.gtturkey.com/UD_OBJS/PDF/RPRARS/Emerging_Markets_Opportunity_ Index2012.pdf. (accessed February 2017.

Tonoyan V., Strohmeyer R., Habib M. and Perlitz M. (2006), "Corruption and entrepreneurship: How formal and informal institutions shape firm behavior in mature and emerging market economies", Academy of management best paper proceedings, Atlanta, 2006, pp. 13-15.

Trivedi, C., \& Stokols, D. (2011). Social enterprises and corporate enterprises: Fundamental differences and defining features. The Journal of Entrepreneurship, 20(1), 11-32

UN Climate Change Newsroom. (2017). Available at: http://newsroom.unfccc.int/unfccc-newsroom/nations-takeforward-global-climate-action-at-2016-un-climate-conference/. (Accessed 24 Feb 2017).

Verma, H. V. (2010). Mission statements - A study of intent and influence. Journal of Services Research, 9(2), 153-172.

Watch, E. (2010). The BRIC countries: Brazil, Russia, India, China. Economy Watch, 30.

Weber, R. P. (1990). Basic content analysis. Newbury Park: Sage.

Williams, L. S. (2008). The mission statement: A corporate reporting tool with a past, present, and future. Journal of Business Communication, 45, 94-119.

Wright, J. N. (2002). Mission and reality and why not? Journal of Change Management, 3(1), 30-44.

Zietlow, J. T. (2001). Social entrepreneurship: Managerial, finance and marketing aspects. Journal of Nonprofits and Public Sector Marketing, 7(12), 19-44.

Submit your manuscript to a SpringerOpen ${ }^{\mathcal{O}}$ journal and benefit from:

- Convenient online submission

- Rigorous peer review

- Open access: articles freely available online

- High visibility within the field

- Retaining the copyright to your article 